\title{
J. Jesús María Serna Moreno, República Domini- cana. Identidad y berencias etnoculturales indi- genas, Santo Domingo, Archivo General de la Nación, 2010, vol. CVIII, 148 pp.
}

Transcurría la década de los años setenta del siglo pasado cuando en una reunión de americanistas conocí a uno de los personajes que me marcaron como estudiosa de las ciencias sociales: era ni más ni menos que Darcy Ribeiro. Debo confesar que me impresionó mucho su conversación y su erudición. Durante esta década marcada por los terribles acontecimientos derivados de las sangrientas represiones, llegaron a México exiliados, compañeros entrañables con quienes compartimos en las aulas el deseo de conocer a nuestros países, pero desde una perspectiva común que era la latinoamericana, surgía así cada vez más el deseo de conocer más a detalle esa realidad. Por eso el haber conocido y leído a Darcy Ribeiro me hizo reflexionar sobre la necesidad que teníamos de salir de la óptica eurocentrista e incursionar por teorías que explicaran desde nuevos enfoques las realidades que vivíamos en el continente americano. También flotaba en el ambiente la necesidad de incursionar en estudios interdisciplinarios que, aunados a las fuentes primarias, nos proporcionaran herramientas para entender el presente a través de nuestros orígenes y de esta forma poder vislumbrar un futuro más acorde a nuestras idiosincrasias. Por esto me interesó tanto el libro de Jesús Serna, ya que toma una parte de la herramienta teórica de Ribeiro, que le sirve para adentrarnos en un aspecto poco estudiado de la realidad caribeña: la presencia indígena, casi anulada en el análisis histórico en esta región, así como su importante herencia en la cotidianidad dominicana.

En este libro Jesús María Serna nos brinda un excelente análisis sobre las sobrevivencias etnoculturales indígenas desde el estudio de la identidad nacional y regional. 
Para poder entender esta temática el autor nos presenta en tres capítulos, conclusiones, bibliografía y personas entrevistadas, un enfoque metodológico con base en una propuesta de raigambre latinoamericana que desarrolló Darcy Ribeiro, así como un manejo riguroso de los conceptos que utilizará, a saber: cultura, etnicidad, diversidad, identidad, identidad étnica, lengua, protoetnia y protocultura, transculturación y el modo de vida "mestizo de Pueblo Nuevo", conceptualizaciones derivadas de la metodología de Ribeiro.

Después presenta un estudio con base en una síntesis de trabajos sobre los taínos y otros grupos étnicos que conformaron los pueblos originarios de la República Dominicana antes de la Conquista para, posteriormente, comprobar la existencia de las sobrevivencias etnoculturales indígenas desde una perspectiva histórica; sobre todo, en los dos primeros siglos después de la llegada de los españoles a las islas caribeñas, donde según el autor, se configuraron una "protoetnia" y una "protocultura" dominicanas. Todo esto complementado con un amplio trabajo de campo y de diversas entrevistas, algo muy novedoso para los estudiosos de las ciencias sociales y, en específico, para los dedicados a la temática de las identidades.

Hablar de cultura en el Caribe es entender que ésta se ha transformado a través de su historia y que hoy en día es producto de múltiples influencias étnicas, raciales, religiosas, etc., y cuyas modificaciones no cesarán en el futuro.

En el caso de la República Dominicana su conformación cultural es resultado de un rico proceso multiétnico, pues cuenta con elementos matrices etnoculturales y raciales, como lo indígena, lo blanco (europeo) y lo negro, amén de otros que llegaron posteriormente como los chinos, árabes, norteamericanos y de otras regiones del mismo Caribe. En fin, un encuentro de diversos orígenes donde actualmente predominan los mulatos, luego los negros y los blancos todo esto unido por un rasgo fundamental que es la lengua donde el autor logra también encontrar elementos tanto europeos como indígenas y africanos.

Para entender la dinámica de estas herencias ante la globalización, Serna ofrece una perspectiva latinoamericanista basada en Darcy Ribeiro, quien propuso que en el continente americano habría tres tipos de pueblos: los Pueblos Testimonio, los Pueblos Trasplantados y los Pueblos Nuevos. Esta última categoría es la que el autor toma como referencia para describir el proceso étnico, es decir, serán aquellos que se formaron por 
la reunión de aquellas poblaciones surgidas del mestizaje de continentes profundamente dispares en cuanto a sus características raciales y del entrecruzamiento cultural de blancos, negros e indios, sobre la base de la dominación ejercida por los primeros como es el caso de los pueblos antillanos. Su característica diferencial es la de pueblos deculturados de su indianidad, de su africanidad y de su europeidad para ser una configuración étnica nueva.

En esas poblaciones predominó por fuerza de la hegemonía colonial el europeo que dio una lengua y una cultura ibérica degradada, pero esta configuración fue reelaborada con valores que clandestinamente fueron impregnados por las culturas indígenas y las africanas dándoles un perfil propio.

Serna sugiere valorar de una mejor manera el aporte indígena; de esta manera en "Pueblos Nuevos" los indios recibieron dos herencias: 1) la fórmula de sobrevivencia ecológica en los trópicos para sobrevivir y poder producir las condiciones materiales de existencia de sus sociedades y; 2) una inmensa contribución genética, ya que el llamado blanco en la población de los Pueblos Nuevos es esencialmente el mestizo, generado por europeos en los vientres de mujeres indígenas. En estos Pueblos Nuevos se dio una amalgama biológica y una aculturación de etnias dispares, dentro de un marco esclavócrata y hacendista que fue muy significativo en el orden cultural. El autor propone una tesis donde hay que considerar que en los estados nacionales se contraponen diferentes proyectos políticos, en los que es necesario tomar en cuenta aquellos rasgos identitarios que deben considerar a lo indígena como un elemento fundamental, aglutinador y sintetizador de la identidad nacional y caribeña de sus pueblos. Se trata, en última instancia, de demostrar que existan o no indígenas en la actualidad, es preciso ver qué tuvo y qué tiene aún lo indígena "en la constitución de la nación y en la elaboración de una cultura nacional en un contexto donde el Estado-nación oculta o niega el papel de lo indígena" en la configuración de lo que, según Ribeiro, serán los Pueblos Nuevos.

Así la protoetnia, antes de una etnia nacional, necesariamente pasó por una etapa en la que indígenas y campesinos de los estratos más pobres generaron un complejo mestizaje creando pequeñas protocélulas étnicas, que ayudaron de base para el desarrollo del proceso integrador de la criollidad y una etnia nacional. Es decir, que un "sector racial como el indígena que se creía eliminado muy 
tempranamente, persistió por suficiente tiempo para que su bagaje cultural sirviera de disolvente en muchos espacios de la cultura general". La inmigración blanca durante los siglos xvII y xviI fue mínima y lenta, y para el xIx en las regiones rurales de las colonias españolas se había articulado y definido una cultura criolla, "mestiza de Pueblo Nuevo", producto de infinidad de elementos diversos en continua transculturación.

Las versiones de la historia oficial en la República Dominicana, y en otras partes del Caribe y de América, que niegan o desvirtúan la presencia indígena en los rasgos constitutivos de lo nacional, tienen que ser modificadas, para lo cual es urgente integrar historias locales con un enfoque global que abarque la historia del Caribe en su conjunto.

La importancia de conocer tanto histórica como antropológicamente los pueblos originarios lleva al autor a enriquecer su análisis con referencias sobre el estudio de textos y autores sobre los taínos, en particular, y en sus señalamientos etnohistóricos como arqueológicos, Serna descubre aspectos importantes como el del tabaco, planta utilizada por curanderos taínos para: extraer enfermedades, expulsar espíritus y aun como saumerio, cuyo conocimiento de su cultivo transmitieron tanto a africanos como a europeos, lo que hará de esta hierba una de las principales plantaciones coloniales y modernas del Caribe. También hay que mencionar la yuca, la pesca con anzuelos, la coa, la hamaca, la canoa, etcétera.

En particular Serna estudia la conformación cultural de la República Dominicana como el resultado de un rico proceso multiétnico con elementos, matrices etnoculturales y raciales originalmente constitutivas como la indígena, la blanca (europea) el negro (los esclavos traídos de África subsahariana) además de componentes étnicos procedentes de otras naciones como ya se mencionó. Así actualmente la manifestación de la cultura dominicana estará constituida por "el encuentro de múltiples elementos provenientes de distintos orígenes, aunque predominen mayoritariamente los mulatos y minoritariamente, lo negro y lo blanco". En el desarrollo histórico de la identidad dominicana desde la Colonia se tuvieron criterios diferenciadores sobre el color y el origen étnico.

Por su historia, el pueblo dominicano desarrolló un discurso nacional de oposición a Haití, así el haitiano se constituyó en el enemigo, la barbarie para la 
cual se construyó una identidad ficticia y a la postre durante la Era de Trujillo, la visión antihaitiana e hispanófila se exacerbó más, llevando a sucesos aberrantes como la masacre de haitianos en 1937 a la cual se le llama coloquialmente "la poda".

Sin embargo, en la República Dominicana no existe un consenso en cuanto a cómo valorar el aporte cultural de los pueblos autóctonos de lo cual trata este trabajo, y lo logra con acierto, da "un punto de vista que, desde una postura latinoamericanista y desde una perspectiva etnocultural, históricamente contextualizada, valora de una manera más objetiva el aporte indígena en el Caribe contemporáneo y en particular en la República Dominicana". Por eso en la "dominicanidad" se trata de ver ciertas persistencias culturales de origen indígena que puedan continuar "vivas" y "actuando" en la identidad etnocultural del pueblo dominicano. El enfoque latinoamericanista de Darcy Ribeiro permite introducir un punto de vista diferente en la discusión y valoración de lo indígena en el Caribe, y en la República Dominicana en específico.

En pocas palabras, Serna propone "mirar con otros ojos y otra perspectiva en el mirar" para abordar nuestra historia "afroindolatinoamericana", compartida en lo que tiene de común en sus conformaciones originarias, pero eso sí, sin dejar de lado ninguno de los componentes básicos etnoculturales, de manera tal que la diversidad no nos divida, sino que implique un nuevo concepto de integración de esas diferencias a partir de un planteamiento dialéctico que reunifique a nuestros pueblos en su destino histórico común. Es replantear la integración latinoamericana desde nuestro origen común para que nos lleve a ver la posibilidad histórica de una reunificación de nuestros pueblos desde la diversidad, la unidad de lo diverso como una posible utopía alcanzable hacia el futuro.

María Eugenia del Valle Prieto Ortega Dirección de Estudios Históricos del INAH 